Marquette University

e-Publications@Marquette

Theology Faculty Research and Publications

Theology, Department of

$1-1-2008$

The Pillar of the World: The Eschatological Role of the Seventh Antediluvian Hero in 2 (Slavonic) Enoch

Andrei Orlov

Marquette University, andrei.orlov@marquette.edu

Published version. Henoch, Vol. 30, No. 1 (2008): 119-135. Publisher Link. (C) 2008 Morcelliana. Used with permission. 


\section{THE PILLAR OF THE WORLD: THE ESCHATOLOGICAL ROLE OF THE SEVENTH ANTEDILUVIAN HERO IN 2 (SLAVONIC) ENOCH}

\section{Introduction}

In chapter 25 of the 2 Enoch the Lord reveals to the translated antediluvian hero some unique details in the mysteries of creation found neither in earlier Enochic booklets nor in any other Second Temple Jewish materials. One of the important parts of this revelation deals with the order of events that preceded the visible creation. The Deity unveils to the seer that prior to visible creation he called out from nothing the luminous aeon Adoil ordering him to become the foundation of the upper things. The account describes the process of Adoil's transmutation into the cornerstone of creation on which the Deity establishes his Throne.

Several distinguished students of Jewish mystical traditions, including Gershom Scholem and Moshe Idel, noticed that this protological account in chapter 25 dealing with the establishment of the created order appears to parallel the order of eschatological events narrated in chapter 65 where during his short visit to earth Enoch conveys to his children the mystery of the last times. ${ }^{1}$ According to Enoch's instruction, after the final judgment time will collapse and all the righteous of the world will be incorporated into a single luminous aeon. The description of this final aeon appears to bear striking similarities with the primordial aeon Adoil portrayed in chapter 25 as the foundation of the created order. The text also seems to hint that the righteous Enoch, translated to heaven and transformed into a luminous celestial creature, is the first fruit of this eschatological aeon that will eventually gather all the righteous into a single entity.

Moshe Idel observes that the motif of incorporation of the righteous into a single aeon recalls the idea of the righteous as the cosmological foundation or pillar of the world reflected in some Jewish mystical writings. The idea of the righteous as the foundation of the world seems also present in 2 Enoch 66 where the final aeon is set in parallel with the protological foundation of the created order - the aeon Adoil.

In light of these correspondences it is intriguing that later Jewish mystical lore often portrays Enoch-Metatron as the cosmic foundation

\footnotetext{
${ }^{1}$ G. Scholem, On the Mystical Shape of the Godhead: Basic Concepts in Kabbalah (New York: Schocken, 1991), pp. 98-101; M. Idel, Ascensions on High in Jewish Mysticism: Pillars, Lines, Ladders (Past Incorporated. CEU Studies in Humanities 2; Budapest: Central European University, 2005), pp. 75ff.
} 
sustaining the world or even as the pillar linking the lower and upper worlds. It is possible that the roots of this tradition about the righteous antediluvian hero as the cosmic foundation of the world can be detected already in the Slavonic apocalypse where Enoch is portrayed as the first fruit of the future eschatological aeon of the righteous and the link between the upper and the lower worlds.

The purpose of this paper is to explore the tradition about EnochMetatron as the foundation of the world and the possible roots of this motif in 2 Enoch.

\section{The Protological Desintegration: Aeon Adoil as the Foundation of the World}

The theme of the secrets of creation occupies an important place in the Slavonic apocalypse. The significance of this esoteric subject among other mysteries which the translated patriarch received during his celestial trip is underlined by the fact that the secrets of creation were conveyed to Enoch personally by the Deity and that this knowledge was never revealed to any other creatures, including the angels. This supra-angelic disclosure given to the visionary after his celestial metamorphosis can be seen as the pinnacle of the esoteric knowledge obtained by the seventh antediluvian hero in the upper realm. Both shorter and longer recensions of 2 Enoch provide an extensive description of this revelation. The initial part of this mysterious disclosure deals with the order of events that had taken place immediately before the visible creation was established. In the shorter recension of 2 Enoch 25 the account has the following form:

And I commanded the lowest things: "Let one of the invisible things come out visibly!" And Adail descended, extremely large. And I looked at him, and, behold, in his belly he had a great age. And I said to him, "Disintegrate yourself, Adail, and let what is disintegrated from you become visible." And he disintegrated himself, and there came out from him the great age. And thus it carried all the creation which I had wished to create. And I saw how good it was. And I placed for myself a throne, and I sat down on it. To the light I spoke: "You go up higher and be solidified and become the foundation for the highest things." And there is nothing higher than the light, except nothing itself. And I spoke, I straightened myself upward from my throne. ${ }^{2}$

2 F. Andersen, "2 (Slavonic Apocalypse of) Enoch," in The Old Testament Pseudepigrapha, ed. J.H. Charlesworth (2 vols.; New York: Doubleday, 1983-1985), vol 1, p. 145. 
The longer recension preserves the general narrative structure of the shorter one while slightly changing some terminology and supplying some small additional details:

And I commanded the lowest things: "Let one of the invisible things descend visibly!" And Adoil descended, extremely large. And I looked at him, and, behold, in his belly he had a great light. And I said to him, "Disintegrate yourself, Adoil, and let what is born from you become visible." And he disintegrated himself, and there came out a very great light. And I was in the midst of the [great] light. And light out of light is carried thus. And the great age came out, and it revealed all the creation which I had thought up to create. And I saw how good it was. And I placed for myself a throne, and I sat down on it. And then to the light I spoke: "You go up higher (than the throne), and be solidified [much higher than the throne], and become the foundation of the higher things." And there is nothing higher than the light, except nothing itself. And again I bowed (?) myself and looked upward from my throne. ${ }^{3}$

The important character of the story is the aeon Adoil envisioned in the text as the starting point of creation. ${ }^{4}$ This enigmatic entity can be seen as the midwife of creation that comes to birth together with it through its creative act. The text emphasizes the enormous size of Adoil, defining him as "extremely large." He is portrayed to be "pregnant" with creation by containing a great aeon in the belly. It is not entirely clear if this is a description of the aeons emanating from one another, the process conveyed in the text through the enigmatic formulae "light out of light." It might also be plausible that Adoil's imagery is somehow connected with the Anthropos myth, especially its version in the Corpus Hermeticum where Anthropos becomes the blueprint for the created order by disintegrating into the physical realm, a motif conveyed in the Poimandres through the erotic metaphor of Anthropos falling in love with Nature. In 2 Enoch too Adoil's disintegration provides the beginning for the visible reality and serves as the foundation on which God is able to establish the first visible manifestation of the created order - his Throne. It is significant that in both recensions the Deity also commands Adoil to become the foundation (Slav. основание) of the highest things. ${ }^{5}$ Adoil is thus clearly envisioned as the foundation or sustainer of creation. This terminological identification of Adoil with the concept of the foundation is important for our study.

\footnotetext{
${ }^{3}$ Ibid. vol 1, p. 144.

${ }^{4}$ On the etymology of the name Adoil, see A. Orlov, "Secrets of Creation in 2 (Slavonic) Enoch," in From Apocalypticism to Merkabah Mysticism: Studies in the Slavonic Pseudepigrapha (SJSJ 114; Leiden: Brill, 2007), pp. 191-194.

${ }^{5}$ M.I. Sokolov, "Materialy i zametki po starinnoj slavjanskoj literature. Vypusk tretij. VII. Slavjanskaja Kniga Enoha Pravednogo. Teksty, latinskij perevod i izsledovanie. Posmertnyj trud avtora prigotovil k izdaniju M. Speranskij," Chtenija v Obshchestve Istorii $i$ Drevnostej Rossijskih 4 (1910), 1-25.
} 
Both recensions stress that Adoil's disintegration provides an important foundation on which the divine Throne is established. The seat of the Deity thus serves here as the locale from which God supervises the unfolding creation. The Throne plays a portentous role in the process of creation being envisioned as the center of the created world.

Another significant feature relevant to our future discussion is the portrayal of Adoil in the longer recension as the "revealer." His revelations, however, encompass not verbal but rather "ontological" disclosure conveyed through the act of changing his nature. This mode of revelation is very important for our future analysis of Enoch's role as the revealer and his "ontological" participation in the disclosure of the eschatological aeon. Adoil's disintegration is identified in the text as the revelation of the created order: "And the great age came out, and it revealed all the creation which I had thought up to create."

Finally, another significant detail in the depiction of Adoil is the repeated references to his luminous nature. The emphasis on the luminosity of the primordial aeon is even more apparent in the longer recension which emphasizes not only the outer shining nature of the protological entity but also his internal luminous state depicted there as the pregnancy with great light: "And Adoil descended, extremely large. And I looked at him, and, behold, in his belly he had a great light ... there came out a very great light. And I was in the midst of the [great] light. And light out of light is carried thus." 6

\section{The Eschatological Reintegration: The Aeon of the Righteous}

The aforementioned primeval account of creation narrated by God in chapters 25 and 26 of the Slavonic pseudepigraphon is later invoked in a very abbreviated form in chapter 65 where Enoch seeks to transmit to his sons and people of the earth the knowledge he received during his celestial trip. In this rather terse account the reader also encounters some additional cosmological details pertaining not only to the beginning of creation but also to its final destiny.

Chapter 65 of 2 Enoch deals with the final instructions which the translated hero of the faith hastens to unveil to humanity immediately before his second and final departure to heaven. The final place of this revelation among other mysteries conveyed by Enoch to humankind during his short visit underlines the significance of this disclosure. In many ways it appears to be set in parallel with the account of the Lord's own instructions about the secrets of creation which Enoch received also at the end of his heavenly trip from the Deity after the preliminary revelations conveyed to him by his psychopomps and angel Vereveil.

\footnotetext{
${ }^{6}$ Andersen, “2 Enoch,” vol. 1, p. 144.
} 
One of the intriguing features of this enigmatic revelation is that not only the format of the delivery of this final mystery transmitted by the seer to human recipients is set in parallel to the secrets of creation revealed by the Lord previously in chapters 25 and 26, but also that the peculiar content in many ways mirrors in rather abbreviated form the familiar conceptual framework of the protological revelation. The shorter recension of 2 Enoch 65:1-11 reads:

"Listen, my children! Before all things existed, (and) before all creation came about, the Lord established the age of creation, and after that he created all his creation, visible and invisible ... When the whole creation which the Lord has created, shall come to an end, and when each person will go to the Lord's great judgment, then the time periods will perish, and there will be neither years nor months nor days, and hours will no longer be counted; But they will constitute a single age. And all the righteous, who escape from the Lord's great judgment, will be collected together with the great age. And <the age $>$ at the same time will unite with the righteous, and they will be eternal. And there will be among them neither weariness nor suffering nor affliction nor expectation of violence nor the pain of the night nor darkness. But they will have a great light for eternity, <and> an indestructible wall, and they will have a great paradise, the shelter of an eternal residence. How happy are the righteous who will escape the Lord's great judgment, for their faces will shine forth like the sun."7

The longer recension provides the following description that differs in several details from the account found in the shorter recension:

"Listen my children! Before ever anything existed, and before ever any created thing was created, the Lord created the whole of his creation, visible and invisible.... And when the whole creation, visible and invisible, which the Lord has created, shall come to an end, then each person will go to the Lord's great judgment. And then all time will perish, and afterwards there will be neither years nor months nor days nor hours. They will be dissipated, and after that they will not be reckoned. But they will constitute a single age. And all the righteous, who escape from the Lord's great judgment, will be collected together into the great age. And the great age will come about for the righteous, and it will be eternal. And after that there will be among them neither weariness <nor sickness> nor affliction nor worry nor want nor debilitation nor night nor darkness. But they will have a great light, a great indestructible light, and paradise, great and incorruptible. For

\footnotetext{
${ }^{7}$ Andersen, “2 Enoch,” vol. 1, pp. 191-193.
} 
everything corruptible will pass away, and the incorruptible will come into being, and will be the shelter of the eternal residences." ${ }^{8}$

The patriarch begins his narration with references to the familiar theme of the primeval aeon already familiar to the reader from the story found in chapter 25. These protological events responsible for the unfolding of creation are then set in parallel with the chain of eschatological actions that according to the authors of the apocalypse will reintegrate the whole creation into a single aeon which will collect all the righteous of the world. According to the text, "all the righteous, who escape from the Lord's great judgment, will be collected together with the great age." The final consummation of all creation into a single aeon recalls the initial protological disintegration of Adoil who once gave birth to the multiplicity of the created forms. The account describes the cataclysmic collapse of the spatial and the temporal order that according to the text will lead to a situation when "all time will perish, and afterwards there will be neither years nor months nor days nor hours. They will be dissipated, and after that they will not be reckoned...."

It appears that the final consummation of the created order in many ways "reverses" its protological unfolding in such a way that reintegration into the final aeon invokes memory of the disintegration of the primeval aeon Adoil. There are several distinctive features that in many ways unify both aeonic subjects.

\section{The motif of luminosity}

One of these features includes the luminosity of both entities. As may be recalled, the symbolism of light permeates the depiction of Adoil who according to 2 Enoch's story not only has a luminous nature, but also is pregnant with the great light. This imagery of the external and internal luminous nature of the primeval aeon is conveyed in the Slavonic apocalypse through the expression "light out of light." Similar to the protological "age," the eschatological aeon is also resplendent with luminosity. Thus according to the longer recension of 2 Enoch 65:10, the righteous constituting the final aeon will "have a great light, a great indestructible light." The shorter recension provides some additional details about the luminosity of the final aeon by telling that the faces of the righteous gathered there "will shine forth like the sun."

\section{The Righteous as the Foundation}

As mentioned earlier, in the protological account dealing with the creation of the world Adoil is decpited as the foundation (Slav. основание)

\footnotetext{
${ }^{8}$ Andersen, “2 Enoch,” vol. 1, pp. 190-192.
} 
of the visible things, both earthly as well as heavenly, including the very seat of the Deity, His Throne. In view of the aforementioned parallelism between the descriptions of the first and the last aeons, it appears that the "eschatological age" is also connected with the idea of the foundation. Although the description of the eschatological aeon does not directly refer to this entity as the foundation, this idea is present in the text through several implicit details.

In commenting on the identification of the final aeon with the righteous, Moshe Idel notes that in Jewish mysticism the righteous are often portrayed as the cosmological foundation of the world. In light of this identification Idel proposes that in 2 Enoch the implicit connection might exist between the protological and eschatological foundations, the first represented by the primeval aeon Adoil and the second by the eschatological aeon of the righteous.

In his book about the symbolism of pillars in Jewish mysticism, Idel refers to a passage from the Book of Bahir that depicts the righteous person as the pillar reaching the heaven:

There is a pillar from earth to heaven, and its name is Tzaddiq, according to the name of righteous men. And when there are righteous men in the world, then the pillar is strengthened, but if not - it becomes weak. And it supports the entire world, as it is written: "the righteous are the foundation of the world." But if it is weakened, it cannot support the world. This is the reason why even if there is only one righteous [in the world], he maintains the world. ${ }^{9}$

Idel points to the assumption about the dual status of the righteous discernable in the Book of Bahir's passage: there are righteous men in the world, but there is also a cosmic righteous and the former depend on the latter. ${ }^{10}$ Idel traces the origins of this concept of the cosmic righteous to the conceptual developments found in the Slavonic Enoch where "the Great Aeon, which is identical to the foundation, passes for the righteous.",11

Idel also discusses the tradition found in b. Hag. 12b where the righteous are depicted not only as the ethical but also as the cosmological foundation of the world :

It is taught: R. Jose says: Alas for people that they see but know not what they see, they stand but know not on what they stand. What does the earth rest on? On the pillars, for it is said: Who shaketh the earth out of her place, and the pillars thereof tremble....But the Sages say: [The world] rests on twelve pillars, for it is said: He set the borders to the

\footnotetext{
${ }^{9}$ D. Abrahams (ed.), The Book of Bahir (Los Angeles: The Cherub, 1994), pp. 160-161.

${ }^{10}$ Idel, Ascensions on High in Jewish Mysticism, p. 80.

${ }^{11}$ Ibid. p. 81.
} 
peoples according to the number [of the tribes] of the children of Israel. And some say seven pillars, for it is said; she hath hewn out her seven pillars. R. Eleazar b. Shammua says: [It rests] on one pillar, and its name is "Righteous," for it is said: But "Righteous" is the foundation of the world. ${ }^{12}$

It may be tempting to construe these rabbinic passages as mere references to the moral behavior that "sustains" the ethical order of the world. Idel, however, observes that the passage from the Hagigah has not just a moral but also a cosmological significance. He remarks that "...the Hagigah, a short but highly influential passage, is a part of mythical cosmology rather than a mode of making sense of religious behavior. To be clear, the basic context of the discussion is cosmology, and its influence on the way in which the righteous should be understood is only an aside." 13

One of the features found in the Hagigah's account is the reference to the sevenfold nature of the world's foundation. ${ }^{14}$ In this respect it is intriguing that the longer recension of 2 Enoch 66:8 insists on the sevenfold nature of the final aeon. According to the text: “...for in that age everything is estimated sevenfold - light and darkness and food and enjoyment and misery and paradise and tortures..." 15 The emphasis on the sevenfold nature of the final aeon in 2 Enoch might point to parallels to the later rabbinic tradition about the seven pillars or foundations on which the earth stands. ${ }^{16}$

\section{Enoch-Metatron as the Foundation of the World}

\section{Enoch's Righteousness}

It does not seem coincidental that the portentous revelation about the final aeon of the righteous comes from the mouth of the seventh antediluvian patriarch, the hero known in Jewish lore for his exemplary

\footnotetext{
${ }^{12}$ b. Hag. $12 \mathrm{~b}$.

${ }^{13}$ Idel, Ascensions on High in Jewish Mysticism, p. 75.

${ }^{14}$ The passage found in the Book of Zohar also speaks about the seven pillars that sustain the creation. Zohar 1:231a reads: "Rabbi Jose began by quoting 'Upon that were its foundations fastened?' (Job 38:6). This verse was spoken by the Holy One, blessed be He, because when he created the world He created it upon pillars, the seven pillars of the world, as it is said 'She has hewn out her seven pillars' (Prov 9:1), but it is not known what these seven pillars stand upon, for it is a profound mystery, the most recondite of all." I. Tishby, The Wisdom of the Zohar: Anthology of Texts (3 vols.; London: The Littman Library of Jewish Civilization, 1994), vol. 2, p. 571. Further in the Zohar the foundation stone of creation which stands in the center of the world representing the foundation of everything defined in the text as "the basis and sustenance of the world" - is described as an entity with "seven eyes": "Come and see. There are seven eyes on this stone, as it is said "Upon one stone are seven eyes' (Zech 3:9)." Ibid. vol. 2, p. 572.

${ }^{15}$ Andersen, "2 Enoch," vol. 1, p. 194.

${ }^{16}$ Idel, Ascensions on High in Jewish Mysticism, p. 75.
} 
righteousness. In light of this connection the motif of Enoch's righteousness should be explored more closely.

The epithet "righteous man" becomes an important designation of the seventh antediluvian hero already in the beginning of his story where his righteousness is juxtaposed to the wickedness of the antediluvian generation and the transgressions of the Watchers. Thus already in the very first verses of one of the earliest Enochic booklets, the Book of the Watchers (1 Enoch 1:2), the patriarch is defined as a righteous man. In 1 Enoch 15:11 we hear again the same designation that now comes from the mouth of the Deity himself: "And he answered me and said to me with his voice: Hear! Do not be afraid, Enoch, (you) righteous man and scribe of righteousness..." ${ }^{17}$ Besides the patriarch's exemplary behavior that allowed him to become the sign of righteousness for future generations, this passage also points to another important office of the seventh antediluvian hero as the teacher of righteousness - an office in which he was desperately attempting to rescue and sustain the moral and cosmological order of the antediluvian world by delivering calls to repentance and oracles of doom which he received from God and angels. Early Enochic materials (1 Enoch 12:4 and 1 Enoch 15:11) therefore repeatedly define him as the scribe of righteousness. ${ }^{18}$

Enoch's connection with the eschatological destiny of the righteous may be already ascertained in the early Enochic writings. Thus according to 1 Enoch, the patriarch travels to the enigmatic location "the paradise of righteousness," which might represent here another designation for the eschatological gathering of the righteous.

As has already been noted, early Enoch booklets seek to highlight the contrast between the righteousness of Enoch and the unrighteousness of the antediluvian generation where interference of the Watchers causes moral and cosmological collapse leading the environment and the human race toward an imminent catastrophe. In this catastrophic chain of events affecting the whole fabric of creation, Enoch can be seen as the righteous one who attempts to sustain the created order, in many ways serving as the pillar of the antediluvian world. This important role of the seventh antediluvian hero as the sustainer and protector of creation is reaffirmed in the Book of Jubilees that depicts the patriarch as the cosmic dam against the waters of the Flood. Thus according to Jub. 4:23, thanks to Enoch "the flood water did not come on any of the land of Eden because he was placed

${ }_{17}$ M. Knibb, The Ethiopic Book of Enoch (2 vols; Oxford: Clarendon, 1978), vol. 2, p. 100.

${ }^{18}$ Josef Milik suggests that the honorific "scribe of righteousness" can be related to the Aramaic term ספר קושטא. Cf. J. Milik, The Books of Enoch (Oxford: Clarendon, 1976), p. 191. George Nickelsburg proposes that the title can be related to the Aramaic ספר די קושטא. G.W.E. Nickelsburg, 1 Enoch I: A Commentary on the Book of 1 Enoch, Chapters 1-36; 81-108 (Hermeneia; Minneapolis: Fortress, 2001), p. 65. 
there as a sign and to testify against all people in order to tell all the deeds of history until the day of judgment." 19

Enoch's role as the pillar sustaining the world was not forgotten in later Jewish materials. Idel's research identifies an important tradition preserved in later Jewish mysticism that portrays the seventh antediluvian hero as the foundation which sustains the world: "...the righteous is the foundation of the world. For [the sake of] one [single] righteous the world is maintained and it is Enoch the son of Yared." ${ }^{20}$ It is apparent that the author(s) of this tradition, which might stem from the early Enochic literature, were informed by the extra-biblical roles and actions of the seventh patriarch who served there as the pillar of the world attempting to sustain the moral and cosmological order of creation in the turmoil of the antediluvian generation.

It should be noted that this understanding of Enoch as the pillar or the foundation of the world is not atypical in Jewish mystical lore where the patriarch's heavenly counterpart, the supreme angel Metatron, was traditionally understood as the force sustaining the world. These cosmological functions were exhibited first in Metatron's role as the governor or the prince of the world ${ }^{21}$ (שר העולם) - an office already discernable in 2 Enoch $^{22}$ - and further developed in Hekhalot mysticism, including the Sefer Hekhalot. ${ }^{23}$ It is intriguing that Enoch-Metatron's governance of the world includes not only administrative functions but also the duty of the physical sustenance of the world. Moshe Idel refers to the treatise The Seventy Names of Metatron where the angel and God seize the world in their hands. ${ }^{24}$ This motif of the Deity and his vice-regent grasping the universe in their cosmic hands invokes the conceptual developments found in the Shicur Qomah and Hekhalot materials where Enoch-Metatron possesses a cosmic corporeality comparable to the physique of the Deity and is depicted as the measurement of the divine Body. ${ }^{25}$

19 J.C. VanderKam, The Book of Jubilees (2 vols.; CSCO 510-11, Scriptores Aethiopici 87-88; Leuven: Peeters, 1989), vol. 2, p. 28.

${ }^{20}$ Idel, Ascensions on High in Jewish Mysticism, p. 85.

${ }^{21}$ The term "world" (עולם) in the angelic title appears to signify the entire creation. Peter Schäfer observes that in rabbinic literature the Prince of the World is understood as an angel set over the whole creation. His duties include praying together with the earth for the coming of the Messiah and praising God's creative work. P. Schäfer, Rivalität zwischen Engeln und Menschen: Untersuchungen zur rabbinischen Engelvorstellung (SJ 8; Berlin: Walter de Gruyter, 1975), p. 55.

${ }_{22}$ On the role of Enoch as the Governor of the World in 2 Enoch, see A. Orlov, The Enoch-Metatron Tradition (TSAJ 107; Tübingen: Mohr-Siebeck, 2005), pp. 159-161.

${ }^{23}$ Igor Tantlevskij observes that in 3 Enoch 8, Enoch-Metatron has qualities by which, according to b. Hag. 12a and Avot de Rabbi Nathan A 27:43, the world was created and is sustained. I.R. Tantlevskij, Knigi Enoha (Jerusalem: Gesharim, 2000), p. 185 [in Russian].

${ }^{24}$ Idel, Ascensions on High in Jewish Mysticism, p. 88.

${ }^{25}$ One of such descriptions can be found in Synopse $\$ 12$ (3 Enoch 9) which portrays the metamorphosis of Enoch's body into a gigantic extent matching the world in length and 
The question, however, remains about how all these later Jewish testimonies portraying Enoch-Metatron as the foundation or the pillar of the world are related to the developments found in 2 Enoch? Is it possible that the authors of the Slavonic apocalypse try to depict Enoch as the eschatological pillar of the world who already participates in the final aeon of the righteous and can thus be seen as the first fruit of this eschatological gathering? In this respect, like Adoil who anticipates the protological aeon that gives the beginning to all creation, Enoch too anticipates the future eschatological aeon when the creation will collapse and all the righteous will be united together. Both Adoil and Enoch can therefore be seen as outstanding exemplars preordained to manifest the protological and eschatological states through their ontological conditions, thus serving as "personifications" of these aeons. Both heroes are united by the quality of their luminosity that serves as an important sign of the beginning and the end of time.

\section{Enoch's luminosity}

2 Enoch 66:11 elaborates the condition of the righteous in the final aeon depicting them as luminous beings: "How happy are the righteous who will escape the Lord's great judgment, for their faces will shine forth like the sun." 26 This tradition about the righteous humans emitting light seems to be implicitly tied in the text to the story of its revealer, the seventh antediluvian patriarch, who himself several chapters earlier underwent a dramatic luminous transformation.

The passage may thus suggest that Enoch, who is depicted in chapter 22 as undergoing luminous metamorphoses before the Face of God that turns him into a shining celestial creature, becomes the very first fruit of this future aeon where all righteous persons would eventually regain the condition of luminosity. The eschatological luminosity here points to the protological condition of Adoil and, more importantly, to the incorruptible luminous state of the Protoplast, a condition that humanity lost after Adam's fall.

breath: "I was enlarged and increased in size till I matched the world in length and breath. He made to grow on me 72 wings, 36 on one side and 36 on the other, and each single wing covered the entire world...." P. Alexander "3 (Hebrew Apocalypse of) Enoch," in The Old Testament Pseudepigrapha, vol. 1, p. 263.

${ }^{26}$ Andersen, "2 Enoch," vol. 1, p. 193. See also 2 Enoch 66:7 (the longer recension): "How happy are the righteous who shall escape the Lord's great judgment; for they will be made to shine seven times brighter than the sun." Andersen, "2 Enoch," vol. 1, p. 194. 


\section{Incorruptibility of Enoch}

Enoch's metamorphoses into a luminous celestial creature presupposes another eschatological trait mentioned in his descriptions of the final aeon of the righteous, namely the state of incorruptibility. In 2 Enoch 65:8-10 Enoch says that at the end of times all the righteous who will escape the Lord's great judgment will eventually attain the condition of incorruptibility since they "will be collected together into the great age ... And they will have a great light, a great indestructible light, and paradise, great and incorruptible. For everything corruptible will pass away, and the incorruptible will come into being, and will be the shelter of the eternal residences." 27

The longer recension's emphasis on the incorruptibility of the future condition of the righteous gathered in the final aeon seems again to recall the patriarch's newly acquired celestial state. One of the important features hinting at the patriarch's incorruptible nature is revealed during his brief visit to earth when after his luminous transformation God send him back to the lower realm to deliver final directions to his children. In 2 Enoch 56, during Enoch's instructions, Methuselah asks his father for a blessing so that he may prepare some food for him to eat. The translated hero, however, politely declines the offer to share earthly food lamenting that nothing earthly is agreeable with his current condition:

Listen, child! Since the time when the Lord anointed me with the ointment of his glory, food has not come into me, and earthly pleasure my soul does not remember; nor do I desire anything earthly (2 Enoch 56:2, the longer recension). ${ }^{28}$

In the shorter recension of 2 Enoch, the patriarch's rejection of food is even more decisive: "Listen my child! Since the time when the Lord anointed me with ointment of my glory, it has been horrible for me, and food is not agreeable to me, and I have no desire for earthly food." 29 Here an important link is made between the changes in his nature during his luminous metamorphoses near the Throne of Glory and his newly acquired condition of incorruptibility, which articulates the future state of the righteous in the final aeon.

Here again, through his connection with the eschatological state of incorruptibility Enoch appears to be fashioned as the first fruit of the future aeon of the righteous, or maybe even as the one who already joined this final age. In this respect it is notable that in 2 Enoch 55 Enoch tells his sons

\footnotetext{
${ }^{27}$ Andersen, "2 Enoch,” vol. 1, p. 192.

${ }^{28}$ Ibid. vol. 1, p. 182.

${ }^{29}$ Ibid. vol. 1, p. 183.
} 
before his final departure that he shall go up to the highest heaven into his "eternal inheritance." 30

\section{Enoch as the Revealer}

As has been previously mentioned, the cosmological account found in 2 Enoch identifies Adoil as the revealer. The process of his disintegration in the narrative is rendered as the revelation of the created order: "And the great age came out, and it revealed all the creation which I had thought up to create." 31

It is intriguing that in the Slavonic apocalypse Enoch is not only envisioned as the first fruit of the last age by bearing many future qualities of this eschatological entity, but he also testifies about it by delivering a verbal revelation about this aeon, the disclosure that never appears in any other part of the pseudepigraphon, even in the elaborated address of the Deity who conveys to the seer the innermost secrets of the universe. The role of the seventh antediluvian hero as the revealer of the most recondite mysteries of the world is not an invention of 2 Enoch authors since this office appears as a constant feature of the hero's biography, already found in the Mesopotamian materials constituting the conceptual background for this figure. Thus one of his Mesopotamian prototypes, the seventh antediluvian king Enmeduranki, is often described as the revealer and the "guardian (lit. guarding) of the secrets (nāsir pirišsti) of the great gods." 32 These titles anticipate the future roles of the patriarch as the revealer and יודע רזים expert in secrets in the Enochic tradition and his designation as ("Knower of Secrets") in the Metatron lore. ${ }^{33}$ Esoteric dissemination will remain one of the major functions of the seventh patriarch in various Enochic traditions that depict him sharing astronomical, meteorological, calendarical, and eschatological knowledge with his sons and other people during his short visit to earth. Knowledge of secrets will also play a significant part in Metatron's duties in the Merkabah tradition where he will be responsible for transmitting the highest secrets to the princes under him, as well as to humankind.

What is striking in 2 Enoch, however, is that the seventh antediluvian patriarch reveals not only by the word of mouth but by the

${ }^{30}$ Ibid. vol. 1, pp. 182-183.

${ }^{31}$ Ibid. vol. 1, p. 144.

${ }^{32}$ H.S. Kvanvig, Roots of Apocalyptic: The Mesopotamian Background of the Enoch Figure and of the Son of Man (WMANT 61; Neukirchen-Vluyn: Neukirchener, 1988), p. 188.

${ }^{33}$ John Collins notes that "Enoch's role as revealer is ... illuminated by the parallel with Enmeduranki. The Sumerian king was admitted into the divine assembly and shown mysteries that included the tablets of heaven and the techniques of divination." J.J. Collins, Seers, Sybils and Sages in Hellenistic-Roman Judaism (SJSJ 54; Leiden: Brill, 1997), p. 45. 
very nature of his ontological situation - i.e., he discloses the condition of the last age through his unique transformation and his righteousness. He thus in many ways anticipates in the present age the things that will occur at the end of time when the righteous of this world will be unified together. Like Adoil who "reveals" the protological aeon concealed in his "belly" by his very nature and disintegration, Enoch too is "pregnant" with the eschatological aeon and thus manifests an ontological state that all the righteous will eventually acquire.

\section{Enoch as the Sacerdotal Foundation}

In our previous discussion about the primordial "pillar" Adoil, it has been noted that he seems to be identified with the upper sacred foundation that serves as the basis for the heavenly Temple represented by the Throne of God which is envisioned in the text as the center of the created order. It is intriguing that, similar to Adoil who serves as the upper foundation of the heavenly Temple, Enoch appears to be envisioned as the sacerdotal foundation of the earthly Temple. In 2 Enoch immediately after Enoch's instructions to his sons before his second and final ascension to the highest heaven, the firstborn son of Enoch, Methuselah, and his brothers constructed an altar at Akhuzan, ${ }^{34}$ the exact location from which Enoch had been taken up. The place of the hero's departure then becomes envisioned in the text as the sacerdotal center of the earthly realm where priestly initiations and expiatory sacrifices involving animal blood take place. It is no coincidence, therefore, that 2 Enoch identifies the place Akhuzan as the center of the world. This enigmatic Slavonic word is traced by scholars to the Hebrew word אחזה, "special property of God," which in Ezek 48:20-21 is applied to Jerusalem and the Temple. ${ }^{35}$

Here, similar to Adoil's protological role connected to the motif of the Throne of the Deity, Enoch's eschatological role is tied to the idea of the earthly counterpart of the Throne, the earthly Temple. The vertical axis of the Throne and the Temple is thus explicitly reaffirmed in the text, as is the horizontal line connecting the protological and eschatological events.

Later in the text Akhuzan also receives the additional protological reaffirmation of being identified with the place of Adam's creation. Here the protological and eschatological "pillars" are erected on the same place and the starting point of creation becomes the place of the beginning of the eschatological consummation.

\footnotetext{
${ }^{34}$ Slav. Ахузань.

${ }^{35}$ Milik, The Books of Enoch, p. 114.
} 


\section{Enoch as the Redeemer}

In Chapter 64 of the longer recension of the Slavonic apocalypse, an interesting tradition can be found pertaining to the patriarch's unique role as redeemer of humanity. The chapter depicts the prostration of the elders of the people and of the whole community before Enoch at the place of his second departure to heaven. The people who came to bow down before the patriarch delivered to Enoch the following address:

O our father, Enoch! May you be blessed by the Lord, the eternal king! And now, bless your [sons], and all the people, so that we may be glorified in front of your face today. For you will be glorified in front of the face [of the Lord for eternity], because you are the one whom the Lord chose in preference to all the people upon the earth; and he appointed you to be the one who makes a written record of all his creation, visible and invisible, and the one who carried away the sin of mankind (2 Enoch 64:4-5). ${ }^{36}$

An important detail in this address is Enoch's designation as "the one who carried away the sin of humankind." This role of redeemer is intriguing and might be related to his salvific mission in the destiny of the future aeon of the righteous. ${ }^{37}$ Here Enoch is envisioned not simply as one among many other righteous persons nor as the righteous person par excellence, but he is the one who is able to bring to righteousness.

It also appears to be significant that the patriarch's redeeming role is conflated in this passage with the theme of visible and invisible creation

\footnotetext{
${ }^{36}$ Andersen, "2 Enoch,” vol. 1, p. 190.

${ }^{37}$ For criticism of the concept of Enoch as redeemer, see G. Macaskill, Revealed Wisdom and Inaugurated Eschatology in Ancient Judaism and Early Christianity (SJSJ 115; Leiden: Brill, 2007), pp. 220ff. While Macaskill's study is important for providing critical insights in the issues of eschatology in the text and especially the role of Enoch as redeemer, his arguments against the possibility of the redeeming office of the seventh antediluvian hero in 2 Enoch appear to be weakened by his misunderstanding of the Slavonic terminology that stands behind the important title of Enoch as redeemer which is rendered in the text through the Slavonic words "otjatel""/ "otimitel'." These nouns, which can be translated literally as the "taker" of human $\sin (\mathrm{s})$, are conveyed in Andersen's English translation through the expression "the one who is taking out the human $\sin (\mathrm{s})$." Andersen's English rendering of the term appears to be a source of confusion for Macaskill who interprets the Slavonic nouns "otjatel",/"otimitel"" as "resultative participles." Cf. Macaskill, Revealed Wisdom, p. 225. It shows that Macaskill does not clearly understand the original Slavonic form of this title of Enoch which serves as the starting point for his argument and in many ways constitutes the terminological nexus of his office as the redeemer of humanity. Still his general analysis of other aspects of the text's eschatology is useful, though it is quite strange that his book that deals with the eschatological dimensions of the text manages to completely ignore the account of the final age and Enoch's eschatological role in relation to this entity.
} 
and his role as the recorder and revealer of cosmological knowledge.$^{38}$ Here again, as in the case of Adoil who serves as the link between the invisible and visible creation, Enoch holds knowledge of the plan not only in relation to the visible created order but also to its invisible counterpart.

\section{Conclusion}

The current study explored the roots of Enoch-Metatron's role as the foundation or pillar of the world prominent in later Jewish mysticism. Although in 2 Enoch the seventh antediluvian hero is never directly named as either the foundation or the pillar, his eschatological role and participation in the eschatological aeon depicts him as the counterpart of the primordial foundation, the luminous aeon Adoil. In view of the later offices of Enoch-Metatron in the Hekhalot materials where the translated hero is portrayed as the sustainer of the created order, it is possible that in the Slavonic apocalypse one can see the rudimentary theological unfolding toward understanding Enoch-Metatron as the eschatological foundation of the world. These intriguing traditions again point to the formative value of the conceptual developments found in the Slavonic apocalypse that in many ways serve as a bridge between Jewish apocalypticism and early Jewish mysticism.

\footnotetext{
${ }^{38}$ The importance of Enoch's writings in the eschatological time is reaffirmed in 2 Enoch where the motif of the glorified righteous is invoked in the context of the eschatological time: "And I will leave a righteous man from your tribe, together with all his house, who will act according to my will. And from his seed another generation will rise, after many, but out of them many will be very gluttonous. Then at the conclusion of that generation the books in your handwriting will be revealed, and those of your fathers, and the earthly guardians (stražie zemnye) [of these books] will show them to the Men of Faith (mužem' věrnym), the ones who loyal to me, who do not invoke my name invalidly. And they will be recounted to that generation, and they will be glorified in the end more than in the beginning." 2 Enoch 35:1-3 (the longer recension). M.I. Sokolov, "Materialy i zametki po starinnoj slavjanskoj literature. Vypusk tretij, VII. Slavjanskaja Kniga Enoha Pravednogo. Teksty, latinskij perevod i izsledovanie. Posmertnyj trud avtora prigotovil k izdaniju M. Speranskij," COIDR 4 (1910), 1-35. The shorter recension offers a similar description: "And I will leave a righteous man from your tribe, together with all his house, who will act according to my will. And from his seed another generation will arise, the last of many, and very gluttonous. Then at the conclusion of that generation the books in your handwriting will be revealed, and those of your fathers, and the earthly guardians (stražie zemnye) [of these books] will show them to the Men of Faith (mužem' věrnym). And they will be recounted to that generation, and they will be glorified in the end more than in the beginning." 2 Enoch 35:1-3 (the shorter recension) Sokolov, "Materialy i zametki po starinnoj slavjanskoj literature," 1.93.
} 


\section{ABSTRACT}

The later Jewish mystical lore often portrays Enoch-Metatron as the cosmic foundation sustaining the world or even as the pillar linking the lower and upper worlds.

The current paper argues that the roots of this tradition about the righteous antediluvian hero as the cosmic foundation of the world can be detected already in 2 Enoch where Enoch is portrayed as the first fruit of the future eschatological aeon of the righteous and the link between the upper and the lower worlds.

Although in 2 Enoch the seventh antediluvian hero is never directly named as either the foundation or the pillar, his eschatological role and participation in the eschatological aeon depicts him as the counterpart of the primordial foundation, the luminous aeon Adoil. In view of the later offices of Enoch-Metatron in the Hekhalot materials where in his celestial version the seventh antediluvian hero is portrayed as the sustainer of the created order, it is possible that in the Slavonic apocalypse one can see the rudimentary theological unfolding toward understanding Enoch-Metatron as the eschatological foundation of the world. These intriguing traditions again point to the formative value of the conceptual developments found in the Slavonic apocalypse that in many ways serve there as a bridge between Jewish apocalypticism and early Jewish mysticism. 